\title{
The Association of Choledochal Cyst and Pancreatitis: A Case Report and Review of the Literature
}

\author{
Koledok Kisti ve Pankreatit Birlikteliği: Olgu Sunumu ve Literatürün \\ Gözden Geçirilmesi
}

\author{
Yeliz Çağan Appak, Cüneyt Günşar², Güzide Doğan', Serdar Tarhan, Erhun Kasırga1 \\ 'Celal Bayar University Faculty of Medicine, Department of Pediatrics, Division of Pediatric Gastroenterology, Hepatology and Nutrition, Manisa, Turkey \\ ${ }^{2}$ Celal Bayar University Faculty of Medicine, Department of Pediatric Surgery, Manisa, Turkey \\ ${ }^{3}$ Celal Bayar University Faculty of Medicine, Department of Radiology, Manisa, Turkey
}

\begin{abstract}
Choledochal cysts are relatively rare congenital anomalies which are characterized by dilatation of the extra-and/or intra-hepatic bile ducts. Pancreatic involvement before choledochal cyst operation might be a risk factor for postoperative pancreatitis. In this case report, we present a patient who had pancreatic enzyme elevation before choledochal cyst operation and who developed acute pancreatitis after surgery.

Keywords: Choledochal cyst, pancreatitis, child
\end{abstract}

\section{ÖZ}

Koledok kistleri oldukça nadir görülen, karaciğer içi ve/veya dışı safra yollarının dilatasyonu ile karakterize konjenital anomalilerdir. Koledok kist operasyonu öncesi pankreas tutulumunun varlığı operasyon sonrası pankreatik komplikasyonlar için risk faktörü olabilir. Burada koledok kist operasyonu öncesi pankreas enzim yüksekliği bulunan ve operasyon sonrasında akut pankreatit gelişen bir olgu sunulmuştur.

Anahtar Kelimeler: Koledok kisti, pankreatit, çocuk

\section{Introduction}

Choledochal cysts are uncommon congenital anomalies of the bile ducts. The incidence of choledochal cyst is reported to be $1 / 100000-150000$ in western societies, whereas it is $1 / 1000$ in Asian societies (1). Although choledochal cysts are usually observed in childhood, they are seen in adults in 25 percent of the cases. Many complications can occur before and after surgery in patients with choledochal cyst. It was argued that pre-operational pancreas involvement could be a risk factor for a possible post-operational pancreatitis (2). This case report aims to discuss the association of choledochal cyst and pancreatitis in the light of the literature, and emphasize the necessity of being careful about acute pancreatitis after choledochal cyst operations.

\section{Case Report}

An 18-month-old male patient was guided to our department upon detection of high aspartate aminotransferase (AST): $220 \mathrm{U} / \mathrm{L}$, alanine aminotransferase (ALT): $295 \mathrm{U} / \mathrm{L}$ in the examinations held upon his vomiting in an eruptive manner 5 to 6 times in the last 2 days following a fever that started 5 days previously. No medication was 
used by the patient who did not have a known disease, but the father had a history of cholelithiasis. At physical examination, body weight was $11 \mathrm{~kg}(25 \mathrm{p})$, height was $84 \mathrm{~cm}(50-75 \mathrm{p})$, the patient did not have a significant sensitivity in the abdomen, and system examinations were normal. White blood cell count was: 6500/uL, hemoglobin: 11,8 g/dL, platelets: 412000/uL, AST: $442 \mathrm{U} / \mathrm{L}, \mathrm{ALT}: 607$ $\mathrm{U} / \mathrm{L}$, total bilirubin: $0.5 \mathrm{mg} / \mathrm{dL}$, direct bilirubin: $0.2 \mathrm{mg} / \mathrm{dL}$, total protein: $7.4 \mathrm{gr} / \mathrm{dL}$, albumin: $4.7 \mathrm{~g} / \mathrm{dL}$, gamma-glutamyl transferase: $486 \mathrm{U} / \mathrm{L}$, amylase: $190 \mathrm{U} / \mathrm{L}$, and lipase was: $227 \mathrm{U} / \mathrm{L}$. Abdominal ultrasonography (USG) showed no dilatation in the intrahepatic bile ducts. The main hepatic bile duct was dilated from proximal to the head of the pancreas, and it measured $2.5 \mathrm{~cm}$ at the widest point. The cystic duct was dilated and was $5 \mathrm{~mm}$. The gall bladder size, the wall, and the lumen were normal. While the total bilirubin rose to $2.4 \mathrm{mg} / \mathrm{dL}$ and the direct bilirubin to 1.8 $\mathrm{mg} / \mathrm{dL}$; AST decreased to $67 \mathrm{U} / \mathrm{L}$, ALT to $185 \mathrm{U} / \mathrm{L}$, amylase to $64 \mathrm{U} / \mathrm{L}$ and lipase to $63 \mathrm{U} / \mathrm{L}$, following the initiation of intravenous hydration therapy. In the abdominal computed tomography (CT), choledoch was observed to be tortuous and dilated, and the largest area was measured as $28 \mathrm{~mm}$. Pre-operative cholangiography revealed the choledochal cyst as Type I A (Figure 1). Choledochal cyst excision, cholecystectomy, Roux-en-Y hepaticojejunostomy, and appendectomy procedures were performed on the patient. On the first post-operative day, the general condition of the patient was good, with amylase: $68 \mathrm{U} / \mathrm{L}$ and lipase: 56 $\mathrm{U} / \mathrm{L}$. With the follow-up, feeding began. On post-operative day 9 , amylase was found to be $1538 \mathrm{U} / \mathrm{L}$ and lipase was $1460 \mathrm{U} / \mathrm{L}$. The patient developed fever and started vomiting. Total parenteral nutritional support, intravenous hydration and antibiotic therapy were initiated and oral nutrition was stopped. Amylase and lipase values gradually decreased and were observed at normal range on postoperative day 23.

\section{Discussion}

Choledochal cysts are congenital anomalies of the bile duct and are defined as the abnormal, disproportionate cystic dilatation of the bile duct. More than $60 \%$ of the cases are diagnosed in the first year of life. The symptoms are often nonspecific and ambiguous as observed in our patient at diagnosis, and clinical findings vary with age in choledochal cysts cases. The three classical findings are abdominal pain, palpable mass in the upper right quadrant and jaundice. Adults may more frequently present complications. Jaundice and acholic stool in the infant, and intermittent biliary obstruction, or recurrent episodes of pancreatitis in the child are probable findings (3).

Choledochal cysts are classified according to the modified Todani classification (Figure 2) (4). Type I is the most common with a rate of $75-85 \%$. In the diagnosis of choledochal cyst, USG is the best method for evaluating intrahepatic and extrahepatic bile ducts, and gallstones.
USG is also important in demonstrating complications such as cystolithiasis, cholangitis, and malignancy. In a study, abdominal pain and jaundice were found to be the most common complaints of patients with choledochal cyst (5). These findings are nonspecific and therefore make the diagnosis difficult, especially during infancy (5). Antenatal diagnosis with USG is also important in terms of the prevention of complications with early surgery $(5,6)$. CT can be used in conditions where distal choledoch duct cannot be monitored due to intestinal gas. CT and USG are useful methods for typing according to the location, size and intra-extra hepatic involvement of the choledochal cysts. Magnetic resonance cholangiopancreatography (MRCP) and endoscopic retrograde cholangiopancreatography (ERCP) are other options in bile duct pathologies. As a highly sensitive and non-invasive examination, MRCP has priority over ERCP in patients with suspected choledochal cysts (7).

There may be many hepatobiliary pathologies associated with choledochal cyst. Cystolithiasis is the most common condition associated with choledochal cyst in adults. Many of the intracystic stones have a soft, muddy and pigmented appearance that supports the biliary stasis, which is the primary etiologic factor. Hepatolithiasis is frequently seen in Type IV A choledochal cysts, and is being observed in increasing frequency in the long follow-up. Pancreatitis is a common complaint of referral for patients, especially adults with choledochal cysts. Cholangitis is also a common complication. Malignancy may occur in the choledochal cyst associated cyst, liver and pancreaticobiliary duct.

Treatment varies according to the type of choledochal cyst and associated hepatobiliary pathology. The treatment of Type I includes the excision of the cyst and Roux-en-Y hepaticojejunostomy. In Type II, the diverticulum is excised, and in Type III, cyst excision with or without sphincterotomy was being performed until very recently. The opening of the choledochal and pancreatic duct into the cyst was important in terms of protecting these ducts in the re-anastomosis. Today, endoscopic sphincterotomy, and opening of the upper part of the cyst is preferred. In Type IV B, as in Type I, dilated extrahepatic cysts are completely excised and Roux-en-Y hepaticojejunostomy is applied. Resection of cysts in Type IV A is contradictive. Increased risk of malignancy has been reported in intrahepatic cysts even after the total excision of extrahepatic cysts. The intraductal disease does not require treatment unless hepatolithiasis, intrahepatic ductal stenosis, and hepatic abscess are present, in which situation the affected segment or lobe of the liver can be resected. If Type $V$ is present in a single hepatic lobe, hepatic lobectomy can be performed. Patients with widespread involvement should be followed closely for the development of liver failure, biliary cirrhosis and portal hypertension. These patients may require liver transplantation (7).

The diagnosis of acute pancreatitis is based on the sudden onset of typical abdominal pain with at least three fold increase in the upper limit of the normal range of amylase or lipase. However, serum amylase and lipase 


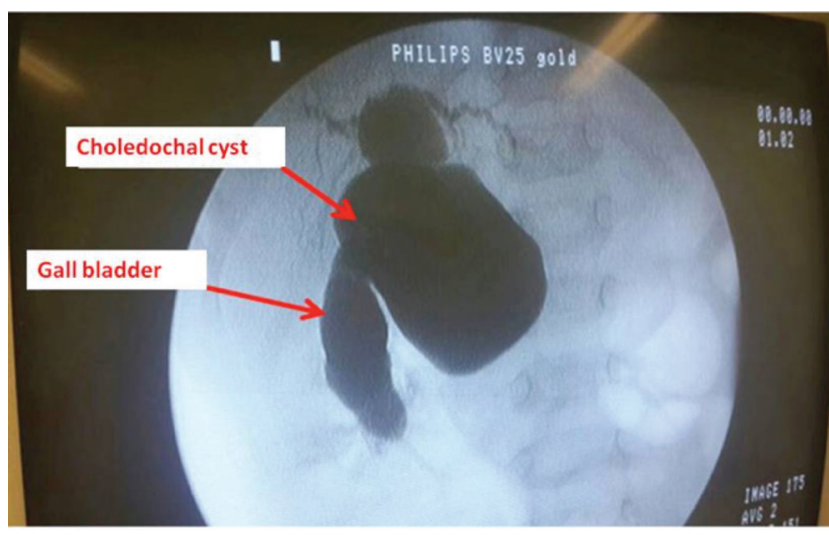

Figure 1. Choledochal cyst image on pre-operative cholongiography

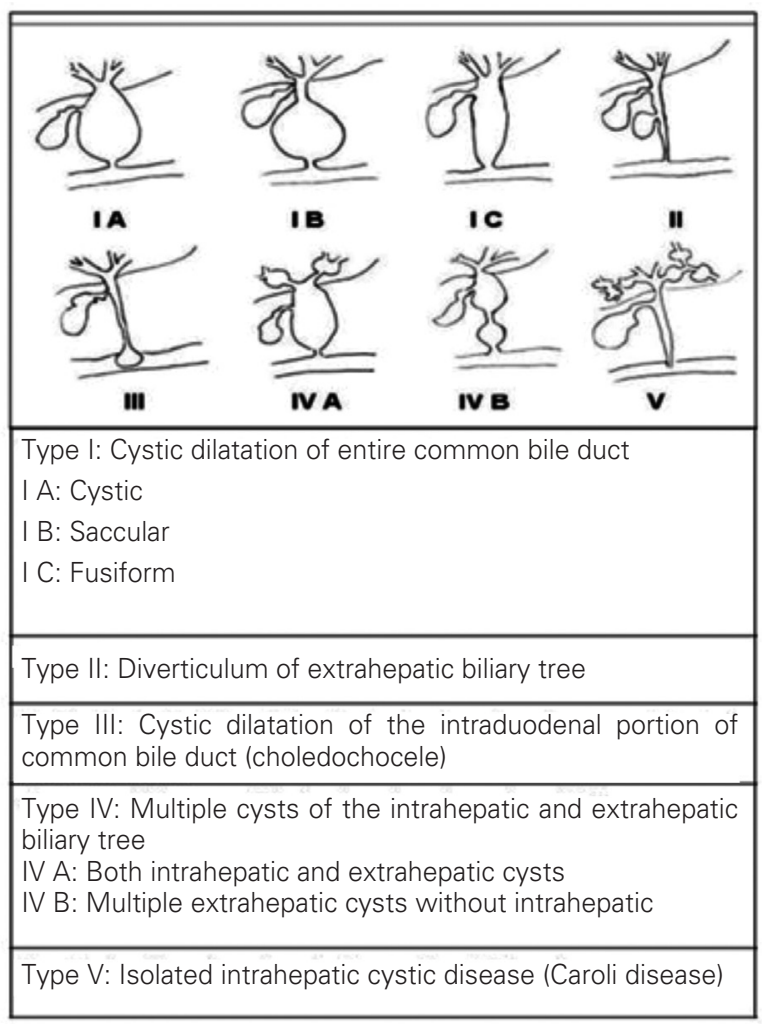

Figure 2. Modified Todani classification of choledochal cysts (9)

may be normal in $20 \%$ of the cases that are clinically and radiologically considered as acute pancreatitis. As observed in our patient diagnosed with choledochal cyst, amylase and lipase elevation in the serum may occur in cases of biliary system diseases, biliary and pancreatic duct obstructions as well as choledochal cyst. Chronic pancreatitis, which is defined as the chronic inflammation of the pancreas, is rarely observed in children. The most important difference between chronic pancreatitis and acute pancreatitis is that the former causes permanent and progressive morphological and functional damage. No evidence of chronic pancreatitis was found in our patient, who presented a high level of lipase and no radiologic evidence of pancreatitis before the operation. He was clinically and radiologically evaluated as acute pancreatitis after the cyst operation.

There are few studies in the literature on the pancreatic complications of choledochal cysts, especially in children. In their study, Fujishiro et al. (2) found that pre-operative pancreatitis was most commonly seen in Todani Type I C among children with choledochal cysts. Following choledochal cyst operation, pancreatitis findings were seen in $9.7 \%$ of patients with pre-operational pancreatitis findings, as was the case with our patient (2). In patients with pancreaticobiliary junction abnormality, reflux of bile to the pancreatic duct, and bile stasis in the distal bile duct may activate pancreatic enzymes and result in pancreatitis. Studies in the field revealed that the incidence of acute pancreatitis in children with choledochal cysts was $0-70.6 \%$, whereas it was observed in a range as wide as $10-54.5 \%$ in adults $(8,9)$. Protein plugs are also common in patients with choledochal cysts. It is argued that bile reflux to the pancreatic duct changes the distribution of pancreatic secretion, and given the mucin production in the bile duct, reflux of the pancreatic fluid to the bile duct, and the activation of pancreatic enzymes result in protein plugs in the choledochal cyst (10). Patients with protein plug formation were found to be highly susceptible to preoperative pancreatitis (2). If protein plugs are soft and fragile, there can be spontaneous regression; the irrigation of the main duct during surgery is a simple and effective way for removing protein plugs. Thus, the risk of post-operative pancreatitis may be reduced (2).

In conclusion, it is important to diagnose the choledochal cyst in the antenatal period, and to treat patients appropriately before any complications develop. It should be kept in mind that patients with pancreatic findings, as in our case, are in the risk group for developing pancreatitis after the operation. Cyst excision and the resolution of bile and pancreatic fluid with hepaticojejunostomy, complete excision of the distal canal, and complete removal of the protein plugs are especially important in cases of choledochal cyst with preoperative pancreatic complications.

\section{Ethics}

Informed Consent: Consent form was filled out by the participant.

Peer-review: Externally peer-reviewed.

\section{Authorship Contributions}

Surgical and Medical Practices: Y.Ç.A., C.G., S.T., E.K., Concept: Y.Ç.A., E.K., Design: Y.Ç.A., G.D., Data Collection or Processing: Y.Ç.A., G.D., Analysis or Interpretation: Y.Ç.A., E.K., Literature Search: Y.Ç.A., Writing: Y.Ç.A.

Conflict of Interest: No conflict of interest was declared by the authors.

Financial Disclosure: The authors declared that this study received no financial support. 


\section{References}

1. Congo K, Lopes MF, Oliveira PH, Matos H, Basso S, Reis A. Outcomes of choledochal cysts with or without intrahepatic involvement in children after extrahepaticcyst excision and Roux-en-Y hepaticojejunostomy. Ann Hepatol 2012;11:536-43.

2. Fujishiro J, Masumoto K, Urita $Y$, Shinkai $T$, Gotoh C. Pancreatic complications in pediatric choledochal cysts. J Pediatr Surg 2013;48:1897-902.

3. Rattan KN, Khurana P, Budhiraja S, Malik V, Pandit SK. Choledochal cyst: a 10-year experience. Indian J Pediatr 2000;67:657-9.

4. Todani T, Watanabe $Y$, Narusue $M$, Tabuchi K, Okajima K. Congenital bile duct cysts: classification, operative procedures, and review of thirty-seven cases including cancer arising from choledochal cyst. Am J Surg 1997;134:263-69.

5. She WH, Chung HY, Lan LC, Wong KK, Saing H, Tam PK. Management of choledochal cyst: 30 years of experience and results in a single center. J Pediatr Surg 2009;44:2307-11.
6. Foo DC, Wong KK, Lan LC, Tam PK. Impact of prenatal diagnosis on choledochal cysts and the benefits of early excision. J Paediatr Child Health 2009;45:28-30.

7. Khandelwal C, Anand U, Kumar B, Priyadarshi RN. Diagnosis and Management of Choledochal Cysts. Indian J Surg 2012;74:401-6.

8. Edil BH, Cameron JL, Reddy $\mathrm{S}$, et al. Choledochal cyst disease in children and adults: a 30-year single-institution experience. J Am Coll Surg 2008;206:1000-5.

9. Tsai MS, Lin WH, Hsu WM, Lai HS, Lee PH, Chen WJ. Clinicopathological feature and surgical outcome of choledochal cyst in different age groups: the implication of surgical timing. J Gastrointest Surg 2008;12:2191-5.

10. Kaneko K, Ando H, Seo T, Ono Y, Tainaka T, Sumida W. Proteomic analysis of protein plugs: causative agent of symptoms in patients with choledochal cyst. Dig Dis Sci 2007;52:1979-86. 